\title{
Site Selection for Public Health Centres (Puskesmas) Using Spatial Multicriteria Analysis in Purworejo Region
}

\author{
Erika Yuliantari ${ }^{1 *}$, Tria Anggita Hafsari ${ }^{1}$, Ryanda Prima ${ }^{1}$ \\ 1 Graduate School of Urban and Regional Planning, Gadjah Mada University \\ *Corresponding Author,Email: erikayuliantari@gmail.com
}

Received: Nov 1, 2017; Accepted: Jan 8, 2018

Key words: Public Health Centre (Puskesmas), Purworejo, Spatial Multicriteria Evaluation, Site Selection

\begin{abstract}
Increasing population size puts pressure on each region, epseically on basic services, such as the provision of clean water, sanitation and health facilities. Centres for public health (Puskesmas) are a basic health facilities provided by the government at the administrative level, with one puskesmas per district. Puskesmas based on this administrative requirement cannot be accessed by the entire community because of their relatively difficult affordability. This study aims to provide advice on the development of puskesmas by modeling their development in consideration of several factors, including the condition of the population, the vulnerability of the population to natural disasters, and spatial factors. This model uses the spatial multicriteria evaluation (SMCE) method based on various scenarios. This research will help decision-makers to choose from various simulation results. Site selection models are tested through crosstabulation against the vulnerability of disease to select the best model. This research was conducted in the Purworejo region, Central Java. The results of this research show that there are varying levels of suitability for site selection. The Bruno district, Kemiri district, Grabag district and Bener district are classified as very suitable, while the Purworejo district and Kutoarjo district are classified as not suitable.
\end{abstract}

\section{INTRODUCTION}

Due to high levels of migration, populations are increasing in almost all cities on the world. This has a positive impact on regional incomes and human resources, however, there are also negative impacts, one of which is the declining quality of the environment, which affects the health of communities. Good public health is crucial to the productive activities of the community, which in turn enhance human development. The government has made efforts to improve public health by building and optimizing puskesmas in every region. Puskesmas are responsible for providing health services, both for the implementation of preventive activities, as well as the control and cure of disease. Being responsible for preventative healthcare, puskemas aim to reduce the prevalence of life-threatening disease (Verter \& Lapierre, 2002).

As a developing country, Indonesia has a high risk of environmentrelated diseases due to its topography, limited access, and tropical climate; 
such diseases include TBC, DHF, diarrhea, philariasis, pheneuomia and malaria (Fitriani, 2013; Tsani, 2013; Wardhani, 2010; Tamza R \& Dharminto, 2013).

The location of health facilities is a key factor that is closely related to the level of community accessibility to health services. Tarigan (2008) defines accessibility as how easy or how attractive a location is to visit compared to other locations. In addition, Daskin and Dean (2005) add that the ease of access of health facilities in a region is related to the amount of illness and death there. Location is an important factor in the success of preventive health programs (Verter \& Lapierre, 2002) and other health programs (Gu, Wang, \& McGregor, 2010).

Another important factor is the aim to have health services well placed geographically within the community itself. Christaller (1933) says that the selection of a location depends on user or consumer factors that are typically associated with supply and demand. Although Christaller's theory focuses on the concept of location development, it can also be applied in other cases, including the case of health centre development. Isrenia (2011) states that health care facilities tend to develop based on accessibility and target consumption; he states that population density is highly correlated to users of health services.

In the context of Indonesia, there are several factors that should be considered in the development of the construction of health centres, such as vulnerability to disasters. Ahmadi-Javid, Seyedi, and Syam (2017) explain that the healthcare sector is also responsible for responding to emergency situations in the case of disaster management and in the mitigation of distster risk; Huang, Kim, and Menezes (2010) explain that healthcare facilities should be able to respond to large-scale emergencies caused by disaster.

Puskesmas as healthcare facilities have so far been built based on administrative requirements; this means the hierarchy of an area is prioritised over the rate of disease there. In practice, environmental health conditions and the development of disease vectors are not limited by administrative boundaries. For health planning, there are many factors that should explicitly be considered (Calvo \& Marks, 1973). Each factor represents the effectiveness of the location of health facilities and rational decision making. The impact of poor decisionmaking on health site selection can lead to inneficient use of resources and poor service delivery. Additionally, Daskin and Dean (2005) explain how the development of poorly sited facilities leads to degraded customer service. Thus, the selection of the best location for puskesmas requires consideration of the physical conditions of the region.

Problems associated with choosing appropriate locations for healthcare facilities have been studied for many years. For example, Varnakovida and Messina (2006) argue for the significance of travel time in optimising healthcare services. The World Health Organization (WHO) (1998) considers size of facility, physical conditions of the region, utilities available, and natural features to be significant. Meanwhile, Wichapa and Khokhajaikiat (2017) argue for the selection of a traditional health location involving only minimal criteria, using mathematical methods to resolve location network problems, so that minimum distance and low cost are prioritised in selecting the best locations.

There are many methods developed to solve the problem, one of which uses a multicriteria decision-making method. This method is selected to address problems that require difficult interpretation with multiple objectives and related allocation of resources, which is a best fit for puskesmas. 
The Analytical Hierarchy Process (AHP), is a method that helps to solve complex problems using mathematical techniques in which the variables are ordered by priority, is utilised in the multicriteria analysis. Using this method, the effect variable is assigned a value, based on its priority, within a pairwise comparison matrix to give a particular structure. In recent years, the use of AHP has been controversial as it gives different results with different decision hierarchies even with the same or similar decision-making objectives (Whitaker, 2007). Wichapa and Khokhajaikiat (2017) add that because it applies an exact value to express the decision-maker's opinion, as opposed to alternatives, it returns unbalanced judgements and results in a subjective model. Additionally, the AHP method cannot represent the decision spatially as an end result of a study. Recently, researchers have integrated AHP with other concepts, such as fuzzy logic and spatial analysis (Chauhan \& Singh, 2016; Wichapa \& Khokhajaikiat, 2017).

The development of Geographic Information Systems (GIS) has enabled the integration of AHP and spatial analysis, and accommodates continuous data, representing it in map form. This method is referred to as Spatial Multicriteria Evaluation (SMCE). This research uses SMCE to choose the best sites for the development of puskesmas in order to offer strategic alternatives for health development; it is based on the following variables: total population of women, population density, disaster vulnerability, existing puskesmas at the location, distance of streets, and landuse arranged in a criteria tree.

\section{RESEARCH METHOD}

\subsubsection{Study Area}

The study area is located on the south side of Java, at $109^{\circ} 47^{\prime} 28^{\prime \prime}$ $110^{\circ} 8^{\prime} 20^{\prime \prime}$ longitude and $7^{\circ} 32^{\prime}-7^{\circ} 54^{\prime}$ latitude, with a total population of 896,631 in 2010. Directly constrained by hills, this region has a varied topography with an average of $70-90 \%$ humidity and average temperature of $22^{\circ}-26^{\circ} \mathrm{C}$. The Purworejo district is one of the areas with highest disease vulnerability. Local health reports state there are at least six sub-districts in this region with endemic malaria, in which the number of sufferers is the highest in Java. In addition, the Purworejo region also has a prevalence of DBD disease, diarrhea, pneuomia and tuberculosis. This condition is exacerbated by the high population growth that is even higher than the population growth in Central Java Province (BPS, 2016a); it must be met with comprehensive health prevention and management programs to facilitate access to health services.

\subsubsection{Tools and Materials}

This research uses the RupaBumi Indonesia Map: the Purworejo region is given at the scale of 1:50,000, and uses the region administration boundaries, and landuse and street base map. Furthermore, this research also uses secondary data for population size, disaster vulnerability, disease incidence in 2015 and existing locations of puskesmas.

This research uses a variety of analysis methods, including ILWIS 3.3, SPSS and ArcGIS 9.3 softwares to process data. ILWIS 3.3 is an opensource software that processes the SMCE model. SPSS is used to perform 
statistical tests. ArcGIS 9.3 is used for spatial data analysis and better map visualisation. It is also used to prepare spatial data, both vector and raster, before analysis using ILWIS 3.3.

\subsubsection{Methodology}

\subsubsection{Spatial Multicriteria Analysis}

The SMCE method considers the priority rank of the variable as the determinant of the decision, using standard GIS procedures. The first step is to determine the objective, in this case the best decision for developing the location of puskesmas. The second step is to determine the object. The object of the study itself is the location of puskesmas, which has several interrelated factors and becomes a consideration in the decision-making. Finally, the third stage is the determination of the criteria tree, shown in Figure 1. The criteria tree defines the calculations to be performed during the analysis, in which multiple maps of attribute entries are combined in accordance with the rules set by the researcher to obtain the final map. This criteria tree consists of the main goal, constraints, factor groups and factors. The main goal must be determined before the data processing is conducted and is referred to as the main root. Constraints are variables that inhibit or interfere in the achievement of goals. The factor group defines some of the goals, and is derived from several factors. Factors are variables used in research that usually support the achievement of goals (Looijen, 2010). In this study, the variables used are those that support the best location selection, however, in the SMCE method these can also be added as variable constraints.

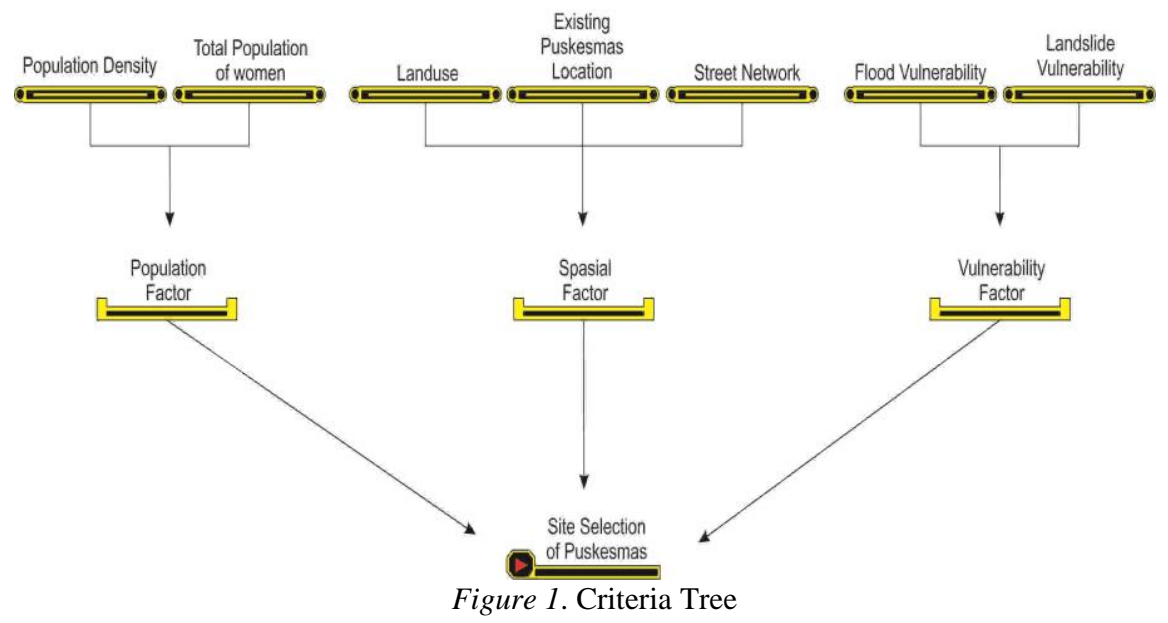

Variables were selected based on assumptions of local conditions and prior studies. The population factor is considered a consumer target indicator, whereas population density is a representation of the population in a certain area. Tarwater and Martin (2001) add that population density, in general, has an impact on the dynamics of the spread of disease. Higher population density in a region means higher disease transmission among humans, especially for infectious diseases. The size of the female population is significant because females tend to be more prone to health problems and they are directly related to children. Spatial factors are important because they illustrate accessibility of health facilities. In Indonesia, the development of puskesmas at the administrative level is governed by an SNI Number 0303-1733-2004. SNI itself is a standard provision used in Indonesia and made 
by the government as a criterion limit. Under the SNI, puskesmas are built to serve one district, a regulation which does not respect the differences in districts' demands regarding their area size and regional conditions; this study accounts for these spatial aspects, in the form of road networks, existing puskesmas and land use. Last is the disaster vulnerability factor, as an indicator for local conditions, which is also stated in the regulations from the ministry of health, which states that health facilities must meet the requirements of geography, one of them being vulnerability to disaster (Minister of Health, 2007). Purworejo region is vulnerable to disaster due to the old soil structure and the local climate. Disasters often occur and claim many casualties.

\subsubsection{Weighting Research Criteria}

The SMCE method uses weighted values to describe how the priorities of variables relate to other variables. The more prioritised a variable is for a particular goal, the higher that variable is weighted for that goal, indicating its influence. The disadvantage of weighting in SMCE is assessment subjectivity: different sources (experts) will provide relatively different values, given the decision-making motivations. The objectivity of AHP is also made uncertain by the structural complexity of the problem. Sometimes observed decisions need to be made immediately, but such complexity cannot be recorded quantitatively, depending on the perceptions and experience of the institution (Saaty, 2008). Therefore, in this study, subjectivity is eliminated by randomising all possible variable priorities, given 72 scenarios and models for selecting locations with different priority orders. Each scenario in the site selection of puskesmas has a different value, which is quantified in the SMCE process.

The randomisation of priority scenarios is shown in Figure 2, which describes how Model 1 was made, with the population factor as the first priority followed by the spatial factor as the second priority and the vulnerability factor as the third priority. In the first model, population density was selected as the first priority and total population of women as the second priority, in the population factor. Subsequent modelling then randomized or mixed the priority order of variables, so that there were 72 models.

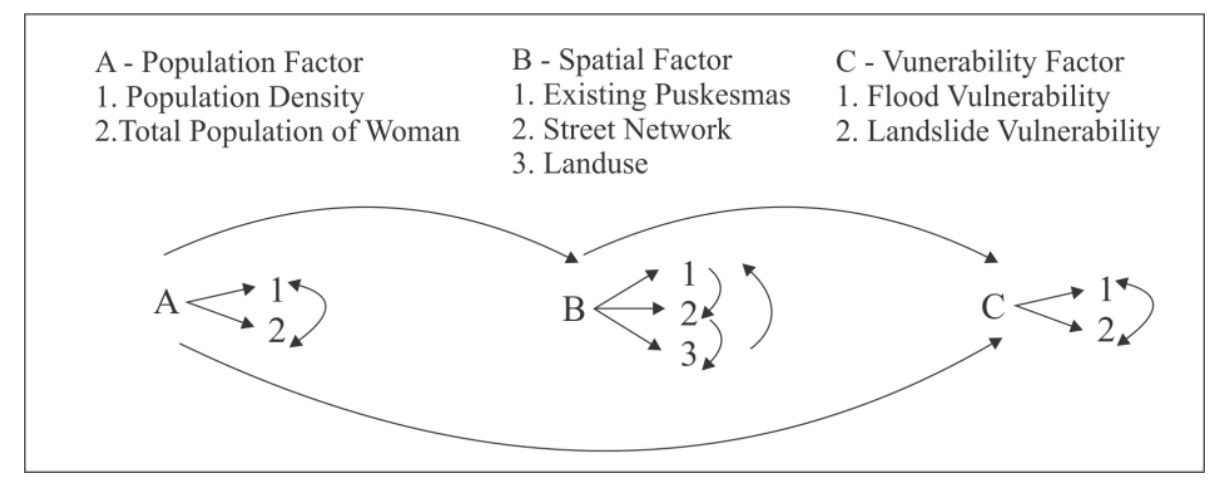

Figure 2. Prioritiy Randomization of Scenario Making 


\section{RESULT AND ANALYSIS}

\subsection{Selection of Best Models}

There are six common diseases in the Purworejo region caused by environmental conditions they are malaria, dengue fever, tuberculosis, diarrhea, pneumia and filariasis. The disease with the highest incidence rate is malaria. This is due to topography and land use. Vegetation density, high rainfall, and hilly topographies are factors that increase the vector development of the disease. The two districts with the highest incidence rates of malaria are the Bagelen and Kaligesing districts, which can be seen in Figure 3. Figure 4 shows the distribution of puskesmas with their disease vulnerability.

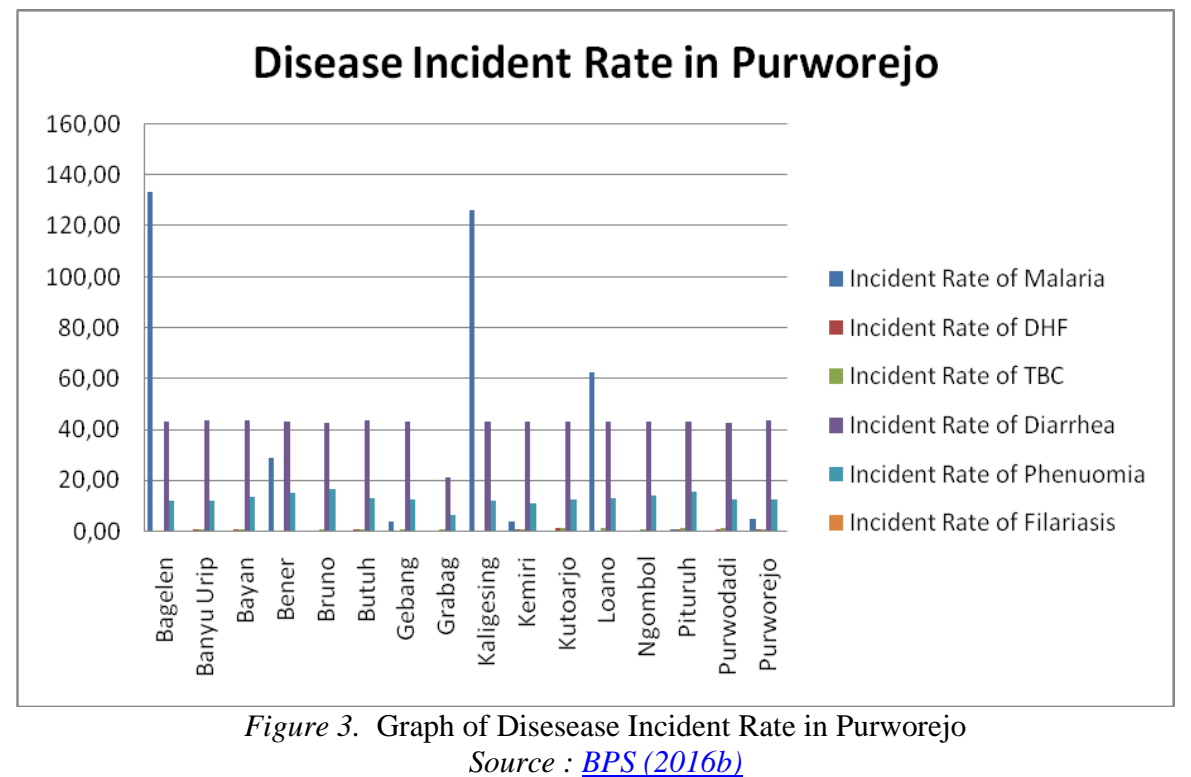

The Bagelen and Kaligesing districts have the highest malaria incidence because they are hilly areas with high vegetation density, while diarrheal diseases infect almost all regions to the same extent. Diarrhea occurs most often due to environmental conditions, sanitation and poor knowledge of hygiene by parents. Diarrheal diseases can be prevented by vaccinating toddlers, environmental improvement and education of healthy living standards.

Disease susceptibility and incidence rates in the Purworejo region are illustrated in Figure 4. On the map, it can be seen that the Kaligesing and Bagelen districts only have one puskesma, while both areas have very high disease vulnerability. In addition, these two sub-districts do not have good accessibility, as indicated by the density of the road networks. On the other hand, the Purworejo district has more than three health centres. This is because this district is the region's capital and has better health services, including from both governmental and private institutions. The Kutoarjo district similarly has more health services even though the area is not vulnerable. Additionally, the Grabag, Purwodadi, and Banyuurip districts have a very non-vulnerable disease incidence rate but still provide health care. 


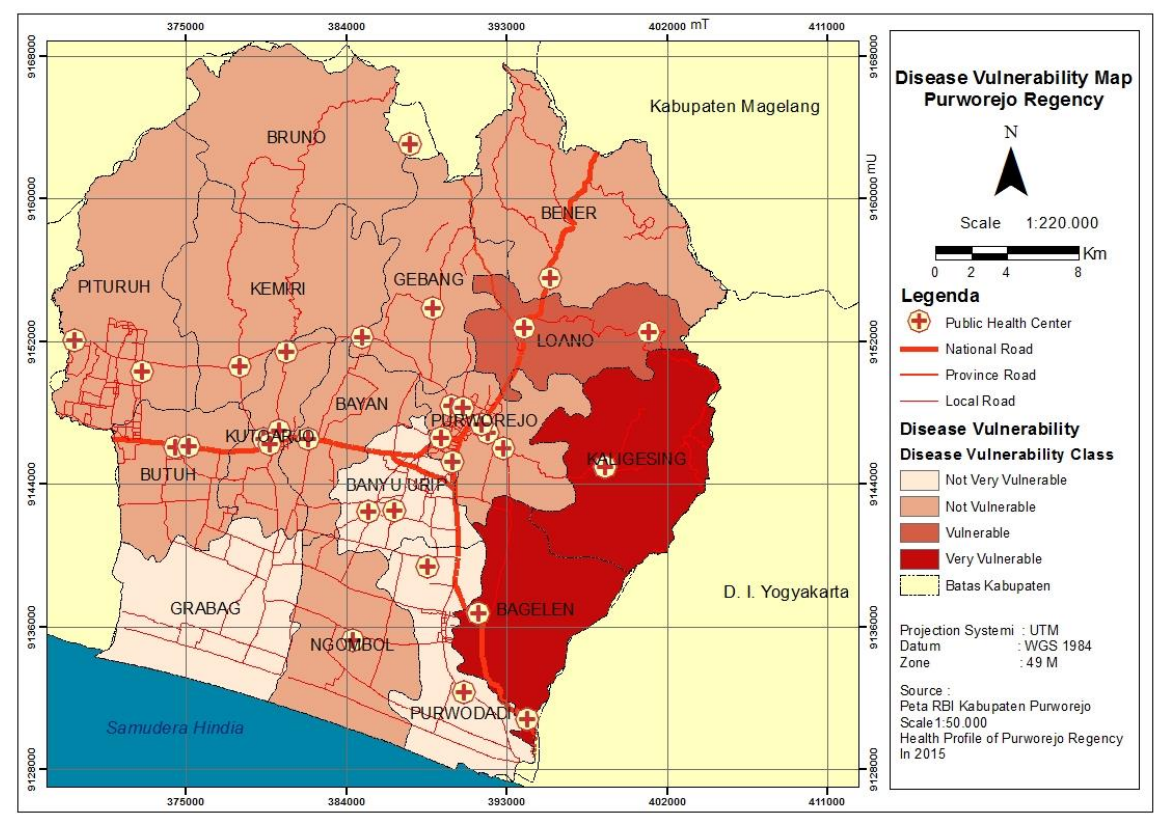

Figure 4. Disease Vulnerability in Purworejo Regency/region

The results from the 72 scenarios show the best location selection map for puskesmas. The 72 models are then compared against the incidence the disease in the Purworejo region using statistical tests to obtain and validate the best model. Validation is the process of determining whether the simulated conceptual model is really an accurate representation of the real system being modeled (Law \& Kelton, 1991). The real system in the context of this research is the condition of disease vulnerability in the Purworejo district. This is based on the assumption that there is a positive correlation between an area's vulnerability to disease and its need for health services.

Validation can be performed in various ways; in this study, the model was tested on a real system, where the model can be said to be valid if it does not show significant difference. The significance of the difference can be assessed statistically, where the test chosen is a descriptive statistic test using crosstabulation, selected by the type and number of data used. The crosstabulation method is used to analyse nominal and ordinal data, which is a technique for comparing the relationship between variables by calculating the percentages of respondents for each group (Widya, 2013). One method of calculation in crosstabulation is the chi square. The chi square test is used to discover if a proportion that is derived from a model is equal to the proportion obtained by a pre-existing theory. In addition, the crosstabulation is a simple tool that is able to describe the relationship between two phenomena more clearly because of its quantitative nature. The analysis of disease vulnerability is conducted using secondary data of disease incidence rates over the past three years. This statistical test is performed using SPSS, where phenomena are said to be related if the calculation results in the Asymp. Sig. column returning less than 0.05 . If the null hypothesis is accepted, the research result cannot be generalised (Hasan, 2004).

The level of significance $(\alpha)$ for the statistical tests is 0.05 , where the total data is 16, describing the number of districts in Purworejo. The level of significance and the number of data influence the $x^{2}$ value shown in the Chi Square Distribution Table. The given value of $x^{2}$ is 24,996. Decision-making is represented by the Asymp. Sig. number and $x^{2}$ (value column). The result 
of the stastistical test shows that some models with null hypotheses are rejected, as shown in Table 1.

Table 1. Result of Statistic Test Using Crosstab; Chisquare

\begin{tabular}{|c|c|r|r|}
\hline & Value & df & \multicolumn{1}{c|}{ Asymp. Sig. } \\
\hline Pearson Chi-Square - Model 26 & $18.184^{\mathrm{a}}$ & 9 & .033 \\
\hline Pearson Chi-Square - Model 28 & $17.524^{\mathrm{a}}$ & 6 & .008 \\
\hline Pearson Chi-Square - Model 32 & $17.524^{\mathrm{a}}$ & 6 & .008 \\
\hline Pearson Chi-Square - Model 36 & $17.524^{\mathrm{a}}$ & 6 & .008 \\
\hline
\end{tabular}

\subsection{Site Selection Model Using SMCE}

The relationship and validation tests conducted in this research intended to check whether the models are applicable to real conditions. The result of the statistical test shows that there are four valid location selection models for health centres relating to the vulnerability of disease in the Purworejo region. Selected locations for puskesmas are expected to provide optimal health services and cover the areas of highest demand. The result of the statistical test shows that model 26 has an Asymp. Sig. value of 0.033, while models 28, 32 and 36 have an Asymp. Sig. value of 0.008; these are the most valid models and represent the location selection. The models can be seen in Figures 5a-d below.

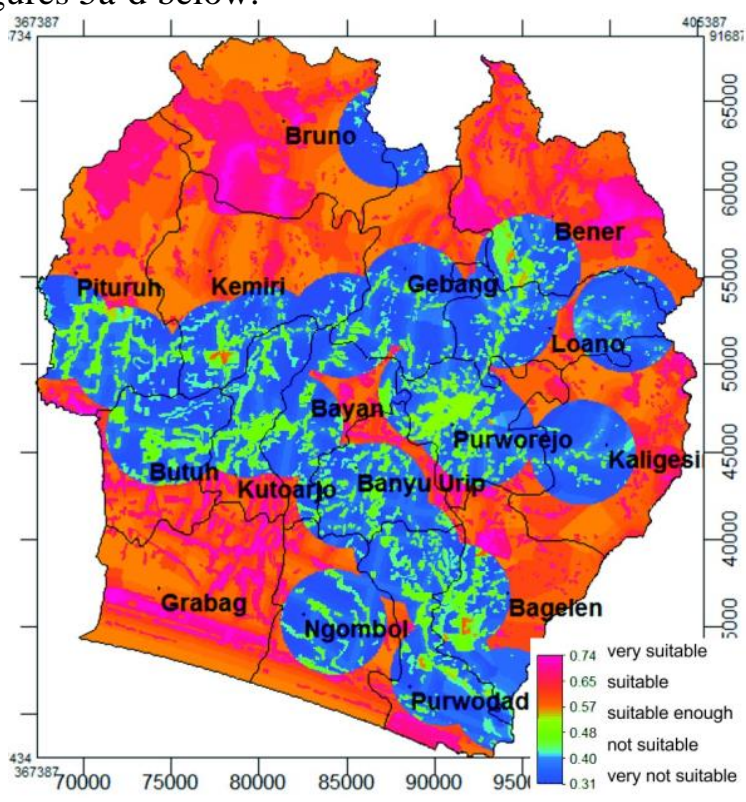

Figure 5a. Model 26

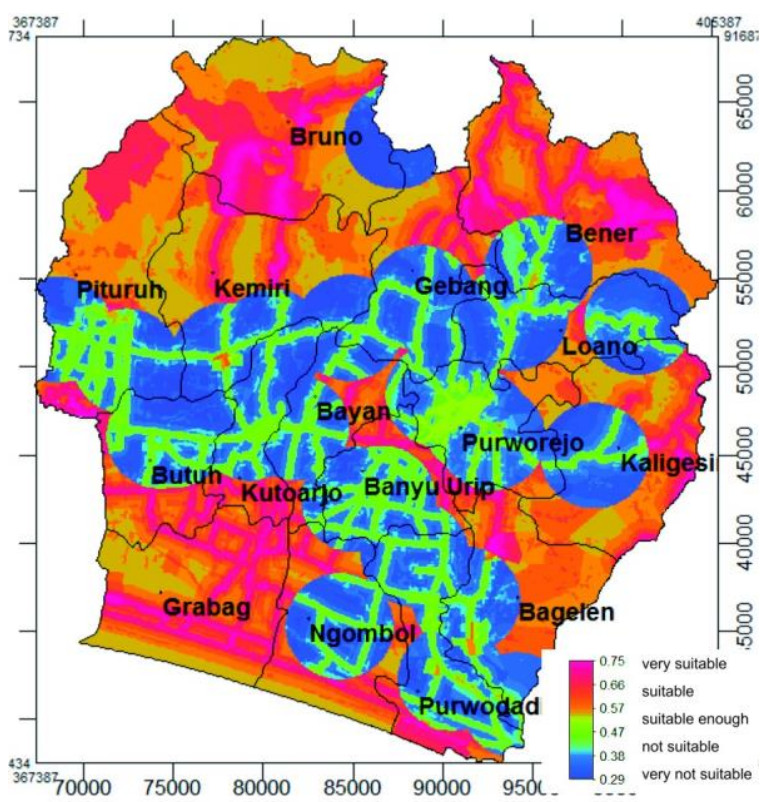

Figure 5b. Model 28 


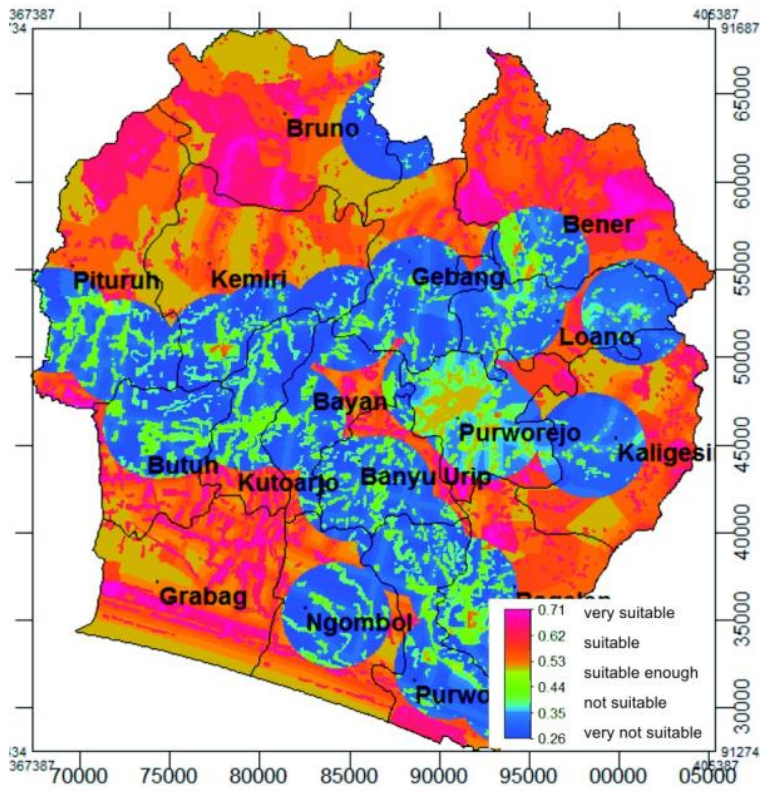

Figure 5c. Model 32

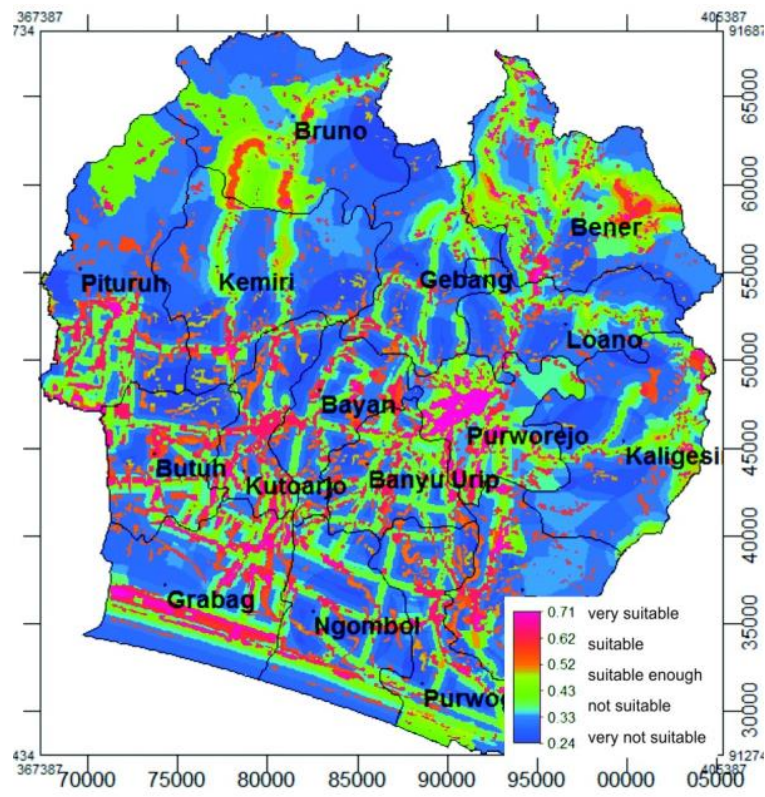

Figure 5d. Model 36

The four models have different priority levels for each variable, which can be seen in Table 2. The best location for puskesmas is almost identical for the three models, 26, 28 and 32, although the value is different. The areas with suitable locations for puskesmas cover most of the Bruno, Grabag, Bener, Bagelen and Kaligesing districts. As shown in Figure 4, the best locations for puskesmas are districts vulnerable to disease that do not have many health care facilities. The other areas, which are not very suitable for puskesmas' site selection, are the Purwodadi, Purworejo, Butuh and Kutoarjo districts. Additionally, model 36 is significantly different from other models; this is because the model prioritizes land use as one of the first priority factors. For more details, the scenarios of each model can be seen in Table 2 .

Table 2. Scenarios of the Best Four Models

\begin{tabular}{|c|c|c|c|c|}
\hline Model & & ario Group & & Scenario Factor \\
\hline \multirow{7}{*}{$\begin{array}{l}\text { Model } \\
26\end{array}$} & \multirow{3}{*}{$\begin{array}{l}\text { First } \\
\text { Priority }\end{array}$} & \multirow{3}{*}{ Spatial Factor } & Priority 1 & Existing Puskesmas' Reach \\
\hline & & & Priority 2 & Land Use \\
\hline & & & Priority 3 & Road Buffer \\
\hline & \multirow{2}{*}{$\begin{array}{l}\text { Second } \\
\text { Priority }\end{array}$} & \multirow{2}{*}{$\begin{array}{l}\text { Natural Disaster } \\
\text { Vulnerability }\end{array}$} & Priority 1 & Flood Disaster Vulnerability \\
\hline & & & Priority 2 & $\begin{array}{l}\text { Landslide } \\
\text { Vulnerability }\end{array}$ \\
\hline & \multirow{2}{*}{$\begin{array}{l}\text { Third } \\
\text { Priority }\end{array}$} & \multirow{2}{*}{$\begin{array}{c}\text { Population } \\
\text { Factor }\end{array}$} & Priority 1 & Population Density \\
\hline & & & Priority 2 & Size of Female Population \\
\hline \multirow{5}{*}{$\begin{array}{c}\text { Model } \\
28\end{array}$} & \multirow{3}{*}{$\begin{array}{l}\text { First } \\
\text { Priority }\end{array}$} & \multirow{3}{*}{ Spatial Factor } & Priority 1 & Existing Puskesmas' Reach \\
\hline & & & Priority 2 & Road Buffer \\
\hline & & & Priority 3 & Land Use \\
\hline & \multirow{2}{*}{$\begin{array}{l}\text { Second } \\
\text { Priority }\end{array}$} & \multirow{2}{*}{$\begin{array}{c}\text { Natural Disaster } \\
\text { Vulnerability }\end{array}$} & Priority 1 & Flood Disaster Vulnerability \\
\hline & & & Priority 2 & $\begin{array}{l}\text { Landslide } \\
\text { Vulnerability }\end{array}$ \\
\hline
\end{tabular}




\begin{tabular}{|c|c|c|c|c|}
\hline & & & Priority 1 & Population Density \\
\hline & Priority & Factor & Priority 2 & Size of Female Population \\
\hline \multirow{7}{*}{$\begin{array}{l}\text { Model } \\
32\end{array}$} & \multirow{3}{*}{$\begin{array}{l}\text { First } \\
\text { Priority }\end{array}$} & \multirow{3}{*}{ Spatial Factor } & Priority 1 & Existing Puskesmas' Reach \\
\hline & & & Priority 2 & Land Use \\
\hline & & & Priority 3 & Road Buffer \\
\hline & \multirow{2}{*}{$\begin{array}{l}\text { Second } \\
\text { Priority }\end{array}$} & \multirow{2}{*}{$\begin{array}{l}\text { Natural Disaster } \\
\text { Vulnerability }\end{array}$} & Priority 1 & Flood Disaster Vulnerability \\
\hline & & & Priority 2 & $\begin{array}{ll}\text { Landslide } & \text { Disaster } \\
\text { Vulnerability } & \\
\end{array}$ \\
\hline & \multirow{2}{*}{$\begin{array}{l}\text { Third } \\
\text { Priority }\end{array}$} & \multirow{2}{*}{$\begin{array}{l}\text { Population } \\
\text { Factor }\end{array}$} & Priority 1 & Size of Female Population \\
\hline & & & Priority 2 & Population Density \\
\hline \multirow{7}{*}{$\begin{array}{l}\text { Model } \\
36\end{array}$} & \multirow{3}{*}{$\begin{array}{l}\text { First } \\
\text { Priority }\end{array}$} & \multirow{3}{*}{ Spatial Factor } & Priority 1 & Land Use \\
\hline & & & Priority 2 & Road Buffer \\
\hline & & & Priority 3 & Existing Puskesmas' Reach \\
\hline & \multirow{2}{*}{$\begin{array}{l}\text { Second } \\
\text { Priority }\end{array}$} & \multirow{2}{*}{$\begin{array}{l}\text { Natural Disaster } \\
\text { Vulnerability }\end{array}$} & Priority 1 & Flood Disaster Vulnerability \\
\hline & & & Priority 2 & $\begin{array}{ll}\text { Landslide } & \text { Disaster } \\
\text { Vulnerability } & \\
\end{array}$ \\
\hline & \multirow{2}{*}{$\begin{array}{l}\text { Third } \\
\text { Priority }\end{array}$} & \multirow{2}{*}{$\begin{array}{l}\text { Population } \\
\text { Factor }\end{array}$} & Priority 1 & Size of Female Population \\
\hline & & & Priority 2 & Population Density \\
\hline
\end{tabular}

The models' scenario factors reflect the priority needs to be satisfied by puskemas. Regarding the spatial factor, the second priority of model 26 is land use, while in model 28 it is the road buffer. For model 32, the difference lies in the population factor in which the size of the female population becomes the main priority.

Model 32 and model 36 have similar scenarios; their differences are due to the main priority of the spatial factors - the spread of existing puskesmas in model 32 and land use in model 36. This results in a map with significant differences. In model 36, the selected location for development of the puskesmas is located in the residential area, while in model 32 it is located on the outskirts of the Purworejo region.

The four models chosen as the best location models are those that have scenarios in which the spatial factor becomes the most important factor for determining the best location. The second factor is consistenty vulnerability to disaster, and the last is the population factor. The method used, SMCE, provides the best location selection option for the construction of puskesmas. In this study, SMCE provides location selection options with several different priority considerations, although none are significant. These results can aid decision-makers in their analysis of the interrelationship of factors, allowing for proper location selection after considering multicriteria factors.

The restriction of goverment administration boundaries for health faciltities should be reviewed. The complexity and entangled factors of site selection can be understood through multicriteria analysis; the goverment can review its policy to reprioritise health facility site selection. Appropriate health facilities, such as puskesmas, and preventative health programs would be more easily accessible to communities in need if government were to undertake such a review.

Using SMCE, selection of the best location is not limited to the use of the supporting variables, since in this study the modelled location selection factors were generalized and the models simplified real-world phenomena. In the future, it will be possible to choose locations with more explicitly 
related variables, such as the social and economic conditions of society. The object compilation stage in the SMCE method is capable of elaborating complex issues within the criteria tree, making it easier to assess and analyse spatial phenomena.

\section{CONCLUSION}

The conclusions that can be drawn from this study are as follows: (1) the SMCE method can be used for modelling the 'best' location for community health centres, which are also validated by reality; (2) there are four preferred models among the 72 scenarios created, with four districts that should be prioritised for the construction of health centres, which are the Grabag, Pituruh, Bruno and Bener districts. The best site selection models all set spatial factors as the first priority. There should be other factors included in SMCE for public health centres, such as amenities and degrees of health, to allow for more precision in selecting suitable areas for developing public health centres.

Consideration of the site selection for the development of puskesmas using the multicriteria method will increase the likelihood of achievinghealth development targets. Health facilities with good locations meet the demand within their areas. The current policy should be revised to include a wider set of factors and multicriteria analysis of site selection.

\section{REFERENCES}

Ahmadi-Javid, A., Seyedi, P., \& Syam, S. S. (2017). "A Survey of Healthcare Facility Location". Computers \& Operations Research, 79, 223-263.

BPS. (2016a). Provinsi Jawa Tengah Dalam Angka 2016 (Jawa Tengah Province in Figures 2016). Semarang: BPS

BPS. (2016b). Purworejo Regency in Fuures 2016 (Purworejo Regency in Figures 2016). Purworejo: BPS.

Calvo, A. B., \& Marks, D. H. (1973). "Location of Health Care Facilities: An Analytical Approach". Socio-Economic Planning Sciences, 7(5), 407-422.

Chauhan, A., \& Singh, A. (2016). "A Hybrid Multi-Criteria Decision Making Method Approach for Selecting a Sustainable Location of Healthcare Waste Disposal Facility". Journal of Cleaner Production, 139, 1001-1010.

Christaller, W. (1933). Central Places in Southern Germany (Translation into English by Carlisle W. Baskin in 1966). Englewood Cliffs, NJ: Prentice-Hall.

Daskin, M. S., \& Dean, L. K. (2005). "Location of Health Care Facilities". In M.L., B., F., S., \& W.P., P. (Eds.), Operations Research and Health Care. International Series in Operations Research \& Management Science (Vol. 70, pp. 43-76). Boston, MA: Springer.

Fitriani, E. (2013). "Faktor Resiko Yang Berhubungan Dengan Kejadian Tuberkulosis Paru (Related Risk Factor of Pulmonary Tubercolosis)". Unnes Journal of Public Health, 2(1), 2-5.

Gu, W., Wang, X., \& McGregor, S. E. (2010). "Optimization of Preventive Health Care Facility Locations". International Journal of Health Geographics, 9, 17. doi: https://doi.org/10.1186/1476-072X-9-17.

Hasan, I. (2004). Analisis Data Penelitian Dengan Statistik (Research Data Analysis with Statstics). Jakarta: PT Bumi Aksara.

Huang, R., Kim, S., \& Menezes, M. B. (2010). "Facility Location for Large-Scale Emergencies". Annals of Operations Research, 181(1), 271-286.

Isrenia. (2011). Distribusi Dan Pemilihan Lokasi Apotek Berdasarkan Sistem Informasi Geografis Di Kota Bandar Lampung (Distribution and Location Selection of Drugstore Based on Geographic Information System in Bandar Lampung City). Yogyakarta: Universitas Gadjah Mada. 
Law, A. M., \& Kelton, W. D. (1991). Simulation Modeling and Analysis. (2 ed.). New York: McGraw-Hill

Looijen, J. (2010). "Risk Based Site Selection of Waste Disposal Using Smce". Retrieved from

http://drm.cenn.org/Trainings/Risk\%20Management\%20and\%20Environmental\%20Asses sment\%20for\%20Spatial\%20Planning/Lectures_ENG/Site\%20selection\%20for\%20waste \%20disposal\%20using\%20SMCE-joan2010.pdf.

Minister of Health. (2007). Pmk No. 949 Criteria of Health Service Facilities. Jakarta: Minister of Health.

Saaty, T. L. (2008). "Decision Making with the Analytic Hierarchy Process". International Journal of Services Sciences, 1(1), 83-98. Retrieved from https://www.colorado.edu/geography/leyk/geog_5113/readings/saaty_2008.pdf.

Tamza R, S., \& Dharminto. (2013). "Hubungan Faktor Lingkungan Dan Prilaku Dengan Kejadian Dbd (Environmental Factors and Human Behavior Relation with Dhf Incident)". Jurnal Kesehatan Masyarakat, 2(3), 360-368.

Tarigan, R. (2008). Perencanaan Pembangunan Wilayah, Edisi Revisi Kedua (Regional Deveopment Planing, Second Revised Edition). Jakarta: PT Bumi Aksara.

Tarwater, P. M., \& Martin, C. F. (2001). "Effects of Population Density on the Spread of Disease". Complexity, 6(6), 29-36.

Tsani, F. R. (2013). "Hubungan Antara Faktor Lingkungan Dengan Kejadian Penyakit Jantung Koroner (Relationship of Environmental Factors and Coronary Heart Disease)". Unnes Journal of Public Health, 2(3), 1-9.

Varnakovida, P., \& Messina, J. P. (2006). "Hospital Site Selection Analysis". Proceedings of IMAGIN annual Conference. Retrieved from http://citeseerx.ist.psu.edu/viewdoc/download?doi=10.1.1.121.4330\&rep=rep1\&type=pdf.

Verter, V., \& Lapierre, S. D. (2002). "Location of Preventive Health Care Facilities". Annals of Operations Research, 110(1-4), 123-132.

Wardhani, E., Pharmawati, K., Sururi, M. R., and Nia, K. (2010). "Diare Pada Balita Di Kelurahan Cicadas Kota Bandung (Diarrhea in Infant in Cicadas Bandung City)".

Whitaker, R. (2007). "Criticisms of the Analytic Hierarchy Process: Why They Often Make No Sense". Mathematical and Computer Modelling, 46(7-8), 948-961.

Wichapa, N., \& Khokhajaikiat, P. (2017). "Solving Multi-Objective Facility Location Problem Using the Fuzzy Analytical Hierarchy Process and Goal Programming: A Case Study on Infectious Waste Disposal Centers". Operations Research Perspectives, 4, 3948.

Widya. (2013). "Test Untuk Data Nominal Dan Ordinal (Test for Nominal and Ordinal Data)". Retrieved from http://widya.lecture.ub.ac.id/files/2013/01/4.-crosstabs.pdf.

World Health Organization (WHO). (1998). District Health Facilities: Guidelines for Development and Operations. Manila: WHO Regional Office for the Western Pacific. Retrieved from http://www.wpro.who.int/health services/documents/district health facilities _guidelines_for_development_and_operation.pdf. 